\title{
Versatile Potentiality of Silicon in Mitigation of Biotic and Abiotic Stresses in Plants: A Review
}

\author{
Paulin Seal, Prabal Das, Asok K. Biswas* \\ Plant Physiology and Biochemistry Laboratory, Centre for Advanced Study, Department of Botany, University of Calcutta, \\ Kolkata, India

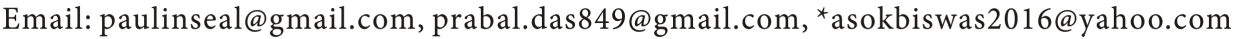

How to cite this paper: Seal, P., Das, P and Biswas, A.K. (2018) Versatile Potentiality of Silicon in Mitigation of Biotic and Abiotic Stresses in Plants: A Review. American Journal of Plant Sciences, 9 , 1433-1454.

https://doi.org/10.4236/ajps.2018.97105

Received: May 7, 2018

Accepted: June 17, 2018

Published: June 20, 2018

Copyright (c) 2018 by authors and Scientific Research Publishing Inc. This work is licensed under the Creative Commons Attribution International License (CC BY 4.0).

http://creativecommons.org/licenses/by/4.0/

\begin{abstract}
The "quasi-essential element" silicon $(\mathrm{Si})$ is not considered indispensable for plant growth and its accumulation varies between species largely due to differential uptake phenomena. Silicon uptake and distribution is a complex process involving the participation of three transporters (Lsi1, Lsi2 and Lsi6) and is beneficial during recovery from multiple stresses. This review focuses on the pivotal role of silicon in counteracting several biotic and abiotic stresses including nutrient imbalances, physical stresses together with uptake, transport of this metalloid in a wide variety of dicot and monocot species. The knowledge on the beneficial effects of silicon and possible Si-induced mechanisms of minimizing stress has been discussed. Accumulation of silicon beneath the cuticles fortifies the cell wall against pathogen attack. Si-induced reduction of heavy metal uptake, root-shoot translocation, chelation, complexation, upregulation of antioxidative defense responses and regulation of gene expression are the mechanisms involved in alleviation of heavy metal toxicity in plants. Silicon further improves growth and physiological attributes under salt and drought stress. Effective use of silicon in agronomy can be an alternative to the prevalent practice of traditional fertilizers for maintaining sustainable productivity. Therefore, soil nutrition with fertilizers containing plant-available silicon may be considered a cost-effective way to shield plant from various stresses, improve plant growth as well as yield and attain sustainable cultivation worldwide.
\end{abstract}

\section{Keywords}

Abiotic Stress, Alleviation, Biotic Stress, Silicon, Silicon Transporter

\section{Introduction}

Stresses encompass multifaceted alterations that dismantle normal functions in a 
plant. Being collective in nature, each stress subsequently summons the other. Plants counteract these undesirable adversities and sustain by inbuilt mechanisms. Significant studies have reported a strong and positive role of Si to sustain the normal functions in plants during diverse environmental stresses. However, under benign conditions, its role is minimal or non-existent. Silicon belonging to group IVA in the periodic table is the seventh most abundant element in the universe and the most abundant tetravalent metalloid in the soil. It is present in the soil solution as silicic acid at concentrations ranging between 0.1 and $0.6 \mathrm{mM}$ [1]. Although abundant, $\mathrm{Si}$ is always combined in the form of oxides and silicates. The agronomically essential phase of $\mathrm{Si}$ is monosilicic acid $\left(\mathrm{H}_{4} \mathrm{SiO}_{4}\right)$. Plants differ in accumulation of Si ranging from $0.1 \%$ to $10 \%$ of shoot dry weight [2]. Members of Poaceae, Equisetaceae and Cyperaceae accumulate Si highly ( $>4 \%)$ while those belonging to Cucurbitaceae, Urticaceae and Commelinaceae accumulate $\mathrm{Si}$ in the intermediate range $(2 \%-4 \%)$, whereas other species show low Si accumulation [1] [3]. These differences have been attributed to the differential uptake ability of roots. $\mathrm{Si}$ is absorbed by plants as silicic acid $\mathrm{Si}(\mathrm{OH})_{4}$ via aquaporin type channels (Nod26-like intrinsic proteins, NIPs) [4] [5]. Silicon nutrition improves growth and yield, provides tolerance to abiotic and biotic stresses, restores macro and micro nutrient balance and is deterrent against herbivores, pest and pathogens [6] [7] [8] [9] [10].

These differences have been attributed to the differential uptake ability of roots. In this review, we elucidate the imperative role of $\mathrm{Si}$ in varied stresses ranging from biotic to abiotic including nutrient imbalances, physical stresses together with uptake, transport of this metalloid. The review compiles aspects that provide an insight to the silicon mediated modifications in physiological mechanisms with improved water uptake, alteration in antioxidative defense management along with enhanced immunity to microbial infections and herbivory.

\section{Silicon Uptake and Transport}

Silicon is absorbed as uncharged silicic acid by the root [11] and is further translocated to shoot where it polymerizes to hydrated, amorphous silica and deposits on the cell wall as silica-cuticle and silica-cellulose double layers. Silicic acid over a critical level (100 ppm at biological $\mathrm{pH})$ polymerizes in the plant body as phytoliths $\left(\mathrm{SiO}_{2} \cdot \mathrm{nH}_{2} \mathrm{O}\right)$ [12]. Silicon uptake is mediated by transporters which were first identified in rice.OsLsil is constitutively expressed primarily in roots and is the first identified gene also responsible for Si uptake in higher plants. Further studies have demonstrated that high $\mathrm{Si}$ uptake by rice is associated with two Si transporters; OsLsi1 and OsLsi2 [4]. Lsi1, a channel-type transporter is an aquaporin protein belonging to Nod26-like intrinsic protein (NIP) III subfamily having permeability to silicic acid while Lsi2, a Si efflux anion transporter actively transports silicic acid from symplast to apoplast towards xylem [11]. Both Lsi1 and Lsi2 are expressed in exodermis and endoder- 
mis of roots with different polarities. Lsi1 localized distally, takes up Si to the cells while Lsi2 at the proximal side actively transports Si to the stele and maintains a low Si concentration in the endodermis and exodermis. Differences in concentration gradient among endodermis, exodermis, cortex and soil solution drives the influx of Si through Lsil. Silicon as monosilicic acid is transported through Lsi1 and Lsi2 to the stele and further reaches the shoot via transpirational flow through xylem [11]. Efficient Si uptake and accumulation depends on the cooperative action of Lsi1 and Lsi2 in rice [13]. A transporter, OsLsi6 responsible for silicic acid transport from xylem to xylem parenchyma cells also influences Si distribution in rice. Both Lsi1 and Lsi6 localized in the plasma membrane, functions as plasma membrane $\mathrm{Si}$ transporters but are expressed differentially. Lsi1 is expressed only in the mature region of roots while Lsi6 is expressed in the immature region near the root tip and also in shoots. Like Lsi1, Lsi6 also belongs to the nodulin-26 like major intrinsic protein III (NIP III), subgroup of aquaporins and is an influx transporter of silicic acid [14] in contrast to Lsi2 which is an active efflux transporter of silicic acid. Lsi6 is found in the xylem parenchyma of leaf sheath and leaf blades. Lsi1 and Lsi2 are involved in Si uptake while Lsi6 transports Si out of the xylem. These were identified in rice which is considered to be a Si-accumulating species [15]. However; plants such as maize and wheat belonging to Poaceae also accumulate high $\mathrm{Si}$ in their shoots but to a lesser extent compared to rice. Two genes, $Z m L s i 1$ and $Z m L s i 6$ have been identified in encoding Si influx transporters in maize are homologs of OsLsi1 and OsLsi6 but their expression pattern and cellular localization is different from OsLsi1.OsLsi1 is localized at the exodermal and endodermal regions of the roots while ZmLsil is localized in epidermis and cortical regions of the lateral roots and in epidermis and hypodermis of the seminal roots. The difference in root structure of these plants is responsible for such variations [16] (Figure 1). Two Casparian bands present in the exodermis and endodermis regions of rice root prevent the passage of minerals to the stele. Additionally, the cortical cells are destroyed and formation of aerenchyma occurs. Therefore, for an efficient transport of Si to the stele OsLsi1 is required both in exodermis and endodermis. However, in maize roots only one Casparian band is located in the endodermis. Therefore, Si taken up by ZmLsi1 in the epidermis and hypodermis may reach to the stele following symplastic pathway. ZmLsi6 is localized mainly in the xylem parenchyma similar to OsLsi6 and primarily functions as a $\mathrm{Si}$ transporter for xylem unloading [16] [17]. Computational studies of silicon transporter proteins in rice and wheat reveal the presence of aquaporin like domains in these transporter proteins. Results obtained from multiple sequence alignment (MSA) studies further confirm the presence of Asn-Pro-Ala (NPA) motifs in plants that is responsible for stress tolerance [18].

\section{Beneficial Effects of Silicon on Plant Growth}

Silicon improves growth and development of plants, particularly those belonging 


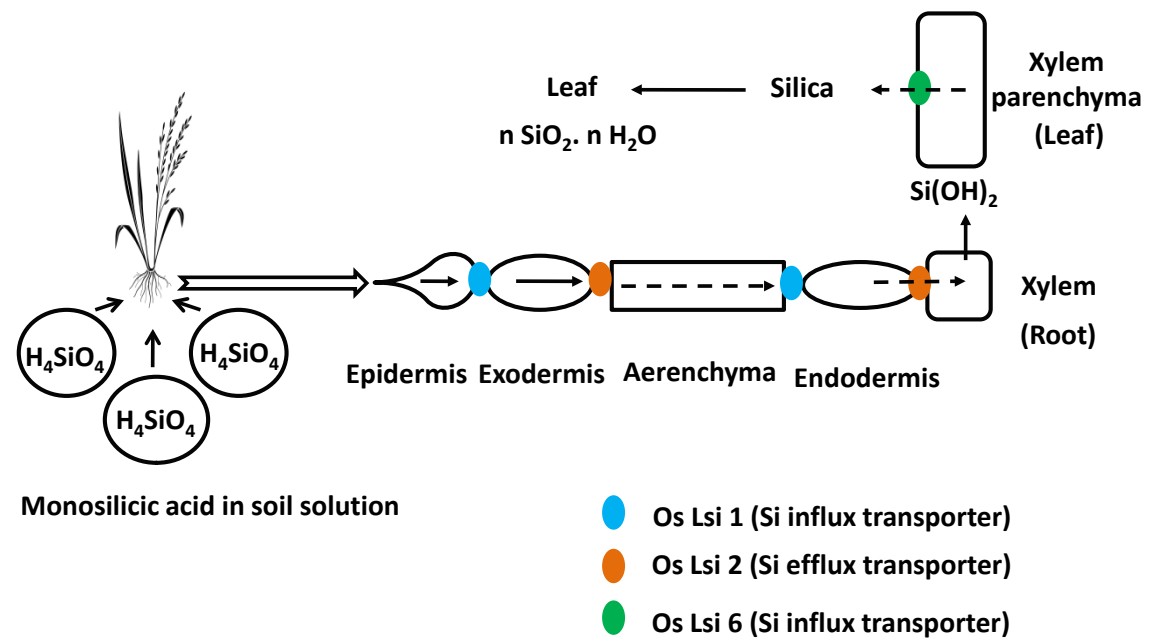

(a)

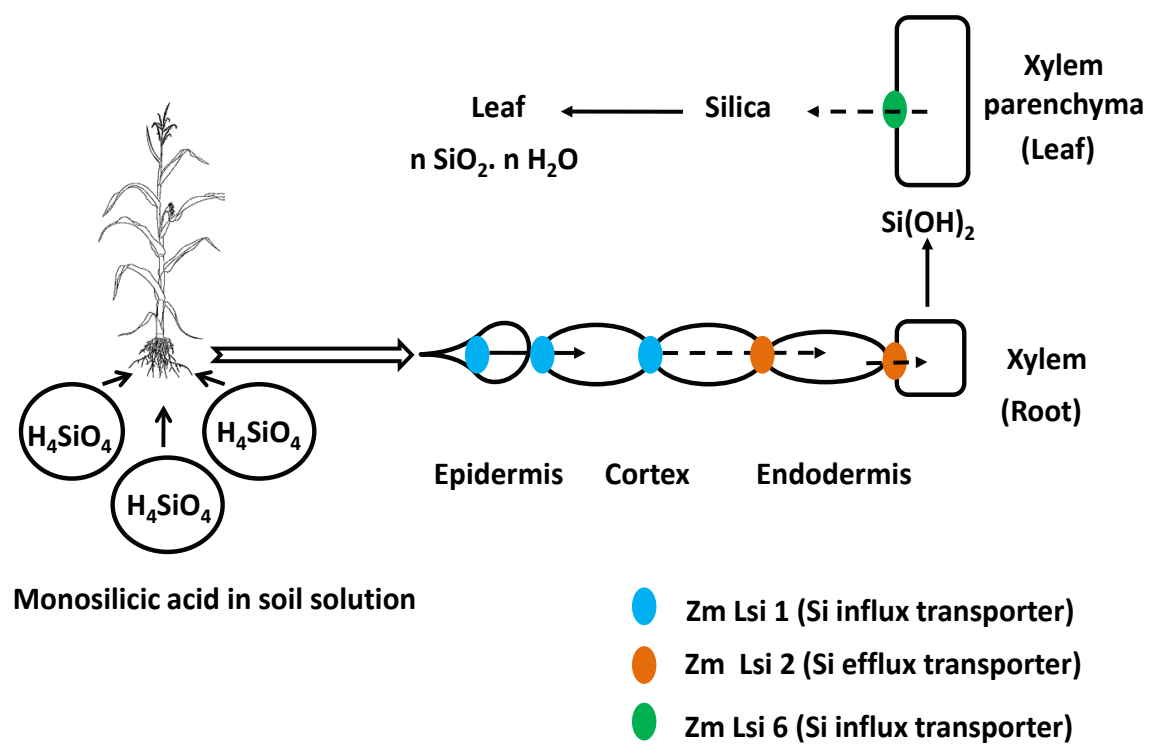

(b)

Figure 1. Schematic representation of Silicon uptake and transport in Rice (a) and Maize (b) root showing transporter mediated process involving Lsil (blue), Lsi 2 (orange) and Lsi 6 (green) (modified from [16]).

to Poaceae and Cyperaceae [19]. The potential benefits of Si include enhancement of growth and yield, improvement of soil penetration by roots, reduction of transpiration mainly due to the deposition of amorphous silica. It enhances resistance against multiple stresses that include several biotic as well as abiotic stresses including nutrient imbalances in plants. Additionally, Si increases resistance to lodging, alleviates metal toxicity, salt and drought stresses [20] [21].

\section{Regulation of Biotic Stresses}

Silicon enhances the growth of monocotyledonous plants by providing rigidity to stems and leaf blades. Energy dispersive X-ray microanalysis and chemical analysis of Si treated plants showed the presence of $\mathrm{Si}$ in awns that improved 
mechanical stability [22]. Silicon addition increased resistance of cucumber plants to the powdery mildew fungus. Additionally, it promoted photosynthesis by enhancing chlorophyll content and RuBP carboxylase activity and stimulated defence reaction mechanisms that enhanced resistance [23]. Silicon induced accumulation of lignin, phenolic compounds, and phytoalexins boost defence mechanisms in the plant [24]. Production of phenolic compounds, callose, or methylaconitate (phytoalexin) occurred in the epidermal cells of Si-fertilized plants [25] [26] [27]. The beneficial effects of Si against pathogens have been explicated in wheat against diseases viz., powdery mildew, septoria and eyespot [28]. Silicon affords protection to rice against stalk rot, rice blast, fusarium wilt, tan spot and leaf spot [29]. Rapid and extensive deployment of natural defences in the plant is triggered by Si either indirectly by sequestering cations or directly by increasing some protein activity during fungal attack. Differential expressions of numerous genes by silicon treatment in Arabidopsis infected by powdery mildew have been demonstrated [30]. Foliar applications of $\mathrm{Si}$ also reduced infection against powdery mildew [31]. Silicon-fed plants translocate silicic acid throughout the plant body. During pathogen attack; the infected tissues synthesize systemic stress signals such as salicylic acid, jasmonic acid and ethylene along with antimicrobial compounds. Thus silicic acid plays a positive role in both local and systemic resistance and enhances production of stress hormones without itself being a secondary messenger [30].

Silicon also limits damages to crops caused by animals, especially insects. Silicon-fertilized grasses are less likely to be eaten by grazing animals [32] [33]. The beneficial effects of Si have been proven on attacks by many other species that include insect borers, yellow borers, rice chlorops, rice leaf hopper, brown leaf hoppers, weaver spider mites, or mites and aphid attacks [29]. Silicon amendment significantly reduced the rice leaf folder survival [34]. Activities of defense-related enzymes, superoxide dismutase (SOD), catalase (CAT), peroxidase (POD), polyphenol oxidase (PPO), phenylalanine ammonia-lyase (PAL) and concentrations of malondialdehyde (MDA) as well as soluble protein in leaves were measured from rice plants grown with or without leaf folder infestation with or without Si treatments. The activities of the said enzymes increased while MDA contents decreased in plants that received $\mathrm{Si}$ amendments. The leaf $\mathrm{Si}$ contents also increased along with the number and width of silica cells.

\section{Regulation of Chemical Stresses}

\subsection{Nutrient Imbalance}

Excess internal inorganic phosphorus $(\mathrm{P})$ has negative effects on plant growth, inactivates metals such as zinc, inhibits activity of enzymes and disrupts cellular osmotic balance. Silicon alleviates P-excess stress by lowering P uptake and decreasing the internal inorganic $\mathrm{P}$ concentration. The damaging effects of excess $\mathrm{P}$ were suppressed by $\mathrm{Si}$ deposition in the endodermis of roots that formed apoplastic barriers against the upward translocation of $\mathrm{P}$ and consequently de- 
creased $\mathrm{P}$ absorption [35]. Silicon decreased $\mathrm{P}$ uptake during presence of excess $\mathrm{P}$ in rice and some non Si-accumulators [36] [37] [38] [39]. Silicon also increases crop yield under P-deficiency stress. Silicon amendments decreased uptake of Manganese $(\mathrm{Mn})$ and Iron $(\mathrm{Fe})$ and increased the availability of internal $\mathrm{P}$ as well as the ratio of $\mathrm{P} / \mathrm{N}$ and $\mathrm{P} / \mathrm{Fe}$ under low $\mathrm{P}$ supply [40]. Nitrogenous fertilizers in excess cause mutual shading, lodging and susceptibility to several diseases. Sufficient Si supply helps in accumulation of $\mathrm{Si}$ in leaf blades and stems of rice decreased the mutual shading and sensitivity of plants to diseases caused by high availability of nitrogen. The occurrence of blast disease considerably decreased in the field after treatment with $\mathrm{Si}$, particularly when excess $\mathrm{N}$ occurred in soil due to dense planting [41].

\subsection{Metal Toxicity}

\subsubsection{On Boron Stress}

Silicon-mediated alleviation of heavy metal toxicity in higher plants has been extensively investigated. Silicon increased tolerance to boron and reduced oxidative damage in wheat [42]. Proline, $\mathrm{H}_{2} \mathrm{O}_{2}$ and MDA content of wheat grown in boron toxic soil considerably reduced by $\mathrm{Si}$ treatments. Silicon concentration of wheat significantly increased with application of Si and counteracted the adverse effects of boron on shoot growth [42] [43]. Silicon also ameliorated boron stress in spinach, barley and tomato by preventing oxidative damage [44]. Formation of boron-silicate complexes in soil reduced boron availability in plants and consequently lowered tissue boron concentration [43].

\subsubsection{On Arsenic Stress}

Silicon administration reduced arsenic concentration in rice root and subsequently lowered arsenic uptake in shoot. Activities of antioxidant enzymes and their isozymes were up-regulated by $\mathrm{Si}$ addition while lipid peroxidation was reduced and concentrations of cysteine, glutathione reduced (GSH) and non-protein thiol (NPSH) were enhanced [45]. Silicon positively altered the toxic effects of arsenic stress in maize by improving the level of chlorophyll along with efficiency in photosynthetic parameters. Alleviation of arsenic stress was dependant on the dose of $\mathrm{Si}$ applied and doses greater than $1 \mathrm{mmol} \cdot \mathrm{L}^{-1}$ increased stress, indicating the existence of an optimal dose of Si for stress alleviation [46]. Silicon supply to three different rice paddy soils reduced arsenic concentrations in rice straw, flag leaf, husk, brown rice, and polished rice [47]. Arsenite uptake and translocation were reduced either due to the decreased expression of $L s i 1$ and $L s i 2$ or due to competitive inhibition at Lsi2 by Si application. Work from our laboratory demonstrated that Si altered arsenic induced reduction in growth, biomass, and photosynthetic pigments in rice and wheat seedlings. This possibly occurred due to $\mathrm{Si}$ mediated reduction in accumulation of oxidative stress markers along with alterations in activities of antioxidant enzymes in the arsenate stressed seedlings. Silicon supplementations under arsenic stress up-regulated the starch synthesiz- 
ing enzymes leading enhanced starch production with a subsequent decrease in both reducing and non-reducing sugar content. The activities of the TCA cycle enzymes particularly dehydrogenases also revived leading to improved growth. Furthermore, Si amendments in arsenic challenged rice and wheat seedlings lowered the accumulation of phytochelatins as well as decreased the activities of thiol metabolizing enzymes when compared to arsenate treatment alone. Disturbances in polyamine homeostasis under arsenate stress was partially revived with $\mathrm{Si}$ supplementations leading to enhanced production of all the three polyamines putrescine, spermidine and spermine along with reduction in $\mathrm{H}_{2} \mathrm{O}_{2}$ content, lipid peroxidation and consequently oxidative stress (Manuscripts under review).

\subsubsection{On Manganese Stress}

The protective role of $\mathrm{Si}$ in response to Manganese toxicity in barley has been established [48]. Silicon lowered apoplastic manganese concentration in cowpea, probably by modulating the cation binding capacity of the cell wall [49]. Manganese adsorption in cell wall was enhanced while soluble apoplastic as well as symplastic manganese contents decreased in presence of Si [50] [51] [52]. Manganese stress tolerance in cucumber by $\mathrm{Si}$ occurred due to stronger binding of manganese to cell wall leading to a decrease in manganese contents within symplast [53].

\subsubsection{On Cadmium Stress}

Silicon markedly alleviated cadmium induced reduction in growth, biomass and photosynthetic parameters in cotton. Electrolyte leakage also significantly reduced with $\mathrm{Si}$ treatments and membrane stability was improved. Exogenous $\mathrm{Si}$ application in solution culture reduced $\mathrm{H}_{2} \mathrm{O}_{2}$ contents and enhanced the activities of anti-oxidant enzymes viz.; SOD, ascorbate peroxidase (APX), POD and CAT under cadmium stress [54]. Alleviation of cadmium toxicity by Si in pakchoi plants has been correlated with an increase in enzymatic as well as non-enzymatic antioxidants and decrease in MDA production (lipid peroxidation) [55]. Silicon limited root to shoot translocation of metal ions in rice seedlings under cadmium stress. Deposition of $\mathrm{Si}$ around root endodermis obstructed the apoplastic bypass flow and controlled apoplastic transportation of cadmium in root [56]. Maize plants grown in low concentration of radiolabelled cadmium $\left({ }^{109} \mathrm{Cd}\right)$, revealed higher levels of cadmium in root compared to shoot. No differences in apoplastic as well as symplastic cadmium distribution were observed between cadmium and cadmium + Si-treated roots while total contents of cadmium increased more than three-fold in cell-wall fraction of cadmium $+\mathrm{Si}$ treated shoots compared to the cadmium-treated counterparts. Silicon induced tolerance of cadmium toxicity in maize might be partially attributed to binding of cadmium in the apoplastic fraction thereby immobilising the metal in the root cell wall and preventing its transport to the cytosol [57]. Silicon covalently binds to heavy metals to form unstable silicates which are degraded to silicon dioxide $\left(\mathrm{SiO}_{2}\right)$ subsequently suppressing toxicity. 


\subsubsection{On Lead Stress}

Silicon markedly alleviated lead induced reduction of growth; biomass, chlorophyll contents and photosynthetic parameters in cotton. Silicon amendments in solution culture markedly reduced MDA and $\mathrm{H}_{2} \mathrm{O}_{2}$ content along with electrolyte leakage and activities of anti-oxidant enzymes viz., SOD, APX, POD and CAT were also enhanced under lead stress [58]. Amendments with nano silicon and Si under lead stress increased biomass and decreased lead concentration in rice. Lead translocation from root to shoot as well as in grains was reduced after Si application and accumulation of lead in grains was blocked [59].

\subsubsection{On Aluminium Stress}

Silicon remitted aluminium toxicity in barley by complexing with aluminium in the medium and/or roots and ultimately inhibited aluminium penetration into root cortex [60]. Silicon ameliorated aluminium provoked root injury in maize causing less root-growth inhibition. Silicon formed biologically inactive complexes of hydroxyl aluminium silicates (HAS) in the apoplast of root and detoxified aluminium decreasing the availability of phytotoxic aluminium in culture media [61]. An enhanced production of flavonoid phenolics like catechin, quercetin was responsible for the Si-induced aluminium resistance in maize [62]. A study in wheat using fluorescent dye morin which binds only to biologically active aluminium revealed less fluorescence in root tips of plants jointly treated with aluminium and Si compared to root tips treated with aluminium alone [63]. Although Si did not reduce the concentration of total aluminium but the concentration of biologically active aluminium within the cell wall was reduced. This was probably because silicic acid retarded aluminium accumulation on the root surface. Silicon markedly alleviated aluminium-induced reduction of biomass and photosynthetic parameters in peanut. Silicon reduced lipid peroxidation, electric conductivity and enhanced antioxidant activities of CAT, SOD and POD under aluminium stress [64]. Silicon immobilized aluminium in roots and reduced its accumulation in cow pea under aluminium toxicity [65]. Formation of aluminium-Si complex in root apoplast reduced aluminium translocation from root to other organs leading to an improvement in pigment content, gas exchange, water use efficiency (WUE), photochemical efficiency of PSII as well as activities of antioxidant enzymes, contributing to a reduction in reactive oxygen species (ROS) accumulation. The mineral imbalance was also reduced and $\mathrm{K}, \mathrm{Ca}, \mathrm{Mn}, \mathrm{Fe}, \mathrm{Zn}$ levels increased. These had positive consequences on growth and photosynthetic capacity.

\subsubsection{On Zinc Stress}

High Zinc stress decreased chlorophyll concentration, chlorophyll fluorescence, stomatal conductance, intercellular $\mathrm{CO}_{2}$ concentration as well as net photosynthesis and inhibited growth in rice. Silicon amendments counteracted zinc induced damages to the photosynthetic parameters and increased the expression of the genes associated with photosynthesis mainly by reducing root to shoot 
transport of the metal [66]. Formation of zinc-silicate complex may be responsible for amelioration of zinc toxicity in heavy metal tolerant Cardaminopsis halleri [67]. Xylem exudate analysis revealed decrease in concentration of zinc in xylem sap of Zinc + Si treatments indicating inhibition of zinc translocation with Si supplementation. Zinpyr-1 fluorescence test and Energy-dispersive X-ray spectroscopy analysis revealed a decrease in concentration of biologically active zinc and co-localization of zinc and $\mathrm{Si}$ in the cell wall of less active tissues, particularly in root sclerenchyma. Si-mediated zinc tolerance in rice has been attributed to reduction in uptake and translocation of zinc. Additionally, binding of zinc in cell wall decreased the concentration of available zinc [68].

\subsubsection{On Chromium Stress}

Silicon reversed the damaging impact of chromium on wheat [69] [70]. Addition of Si along with chromium restricted the entry and accumulation of chromium and consequently mitigated chromium toxicity in wheat. In chromium treated seedlings, mesophyll cells containing chloroplasts showed severe chlorosis, reduced lignification and structural integrity of xylem and phloem were affected. Addition of Si remitted the negative effects of chromium in wheat seedlings. Silicon markedly alleviated chromium mediated impacts on fluorescence parameters viz.; minimum fluorescence $\left(\mathrm{F}_{0}\right)$, maximum fluorescence $(\mathrm{Fm})$, variable fluorescence $(\mathrm{Fv})$, variable/maximum fluorescence ratio $(\mathrm{Fv} / \mathrm{Fm})$, variable/minimum fluorescence ratio $\left(\mathrm{Fv} / \mathrm{F}_{0}\right)$ and maximum/variable fluorescence ratio $(\mathrm{Fm} / \mathrm{Fv})$ and supported better growth of wheat seedlings. The distribution of elements studied by laser-induced breakdown spectroscopy (LIBS) and inductively coupled argon plasma emission spectrometry (ICAP-AES) confirmed betterment in nutritional status with $\mathrm{Si}$ treatments. Chromium transportation in both root and aerial parts of plants reduced with the application of Si which might be a strategy for alleviation of chromium toxicity in wheat. Further, under Si+ chromium treatment, suberization and lignification increased and vascular bundles became well arranged compared to only chromium treated seedlings. Silicon addition also protected internal structures of leaf and root, the root hair frequency increased that might be an approach to sustain stress [71].

\subsubsection{On Nickel Stress}

Silicon application increased growth and biomass under nickel stress in cotton probably due an increase in nutrient uptake. Silicon mediated increase in the activities of antioxidant enzymes decreased the level of ROS, reduced electrolyte leakage and accumulation of MDA and $\mathrm{H}_{2} \mathrm{O}_{2}$ in cotton plants under nickel stress. Silicon application significantly decreased nickel accumulation in leaf, stem and root which probably increased plant growth attributes and biomass [72].

\subsubsection{On Copper Stress}

Supplemental Si has been shown to counteract Copper toxicity in Zinnia elegans and Antirrhinum majus. Both species responded to Si with evidences of reduced stress and nutrient concentrations comparable to control plants [73]. Copper 
induced increase of phenylalanine-ammonia lyase (PAL) activity in Arabidopsis thaliana was reduced with Si treatment suggesting reduced stress. Lower levels of phenolic compounds probably down regulated PAL activity resulting in fewer substrates for oxidative enzymes and reduced oxidative stress [74]. Copper transporter-I (COPT1) was induced by high levels of copper while Si and copper treatment caused a reduction of COPT1 expression. Another gene, HMA5 encoding a heavy metal transport ATPase subunit, expressed in root pericycle responsible for exporting copper to shoots was also induced by high levels of copper. However, Si treatment suppressed the expression of $H M A 5$ in the presence of copper. The possible mechanism for inhibition of metal transport in plants by Si involves numerous aspects. Silicon induces lignin deposition in cell wall which binds metal ions and reduces root to shoot translocation of metals. The unstable silicate complexes formed due to Si-heavy metal covalent linkage subsequently suppresses metal toxicity and further degrades to silicon dioxide $\left(\mathrm{SiO}_{2}\right)$. The extracellular activity of Si limits penetration of heavy metals to the cytoplasm while intercellular activity involves its sequestration in vacuoles.

\subsection{Salinity and Drought Stress}

Silicon mediated amelioration of growth inhibition in rice in response to $\mathrm{NaCl}$ has been reported [75]. Silicon induced an increase in growth and plant biomass under salt stress due to enhanced stomatal conductance and net $\mathrm{CO}_{2}$ assimilation rates and improved ultra structural organization of chloroplasts [76]. Silicon supplements improved plant defense by detoxifying reactive oxygen species under salinity and increased chlorophyll content as well as photochemical efficiency of PSII [77].

The effect of Si on salt tolerance of tomato, cucumber and rice has been related to alterations in antioxidant enzyme activities [77] [78] [79]. Silicon mediated increment in activities of antioxidant enzymes like SOD, CAT, POD as well as glutathione reductase (GR) activities along with GSH contents in salt-stressed plants was reported [77] [78] [79] [80] [81]. Silicon helped to maintain membrane integrity by suppressing membrane lipid per oxidation and decreased membrane permeability [82]. Silicon also ameliorates nutrient imbalances in plants under abiotic stress [83]. Si-treated plants had higher concentrations of essential nutrients particularly $\mathrm{P}$, suggesting that $\mathrm{Si}$ had a potential role on nutrient balance of plants affected by salt stress. Under saline condition, silicon reduced $\mathrm{Na}^{+}$contents in rice, sugarcane and purslane by reducing sodium uptake [84] [85] [86]. Restriction of $\mathrm{Na}^{+}$uptake in rice was due to silica deposition in leaves which consequently reduced transpiration [75]. Additionally, Si polymerization and deposition in the exodermal and endodermal layers of roots limited sodium uptake and accumulation under salinity [76] [84]. Silicon deposition in root and stem provides binding sites for salts, and restricts $\mathrm{Na}^{+}$translocation to shoots thus reducing the ratio of shoot $\mathrm{Na}^{+} /$root $\mathrm{Na}^{+}$[85]. Silicon amendments increased $\mathrm{K}^{+}$conductivity and improved the $\mathrm{K}^{+} / \mathrm{Na}^{+}$ratio by acti- 
vating the root plasma membrane $\mathrm{H}^{+}$ATPase pump. As a result optimal membrane fluidity was maintained along with an enhancement in plasma membrane $\mathrm{H}^{+}$ATPase activity under $\mathrm{NaCl}$ stress [87]. An improvement of $\mathrm{K}^{+}$transport by $\mathrm{Si}$ application was due to the effect on flux through $\mathrm{K}^{+}$ion transporters. Salt tolerance due to $\mathrm{Si}$ application has been attributed to selective uptake and transport of $\mathrm{K}^{+}$and $\mathrm{Na}^{+}$by plants [88]. $\mathrm{K}^{+}$contents increased with an increase in concentration of Si under salt stress in sugar cane and wheat [85] [89]. Silicon also plays significant role in salt tolerance of a halophyte through effects on photosynthetic apparatus water use efficiency (WUE) and mineral nutrient balance however, the mechanisms are not clear. Matoh et al. [75] suggested that silica deposition in leaf decreased transpiration and therefore, decreased salt accumulation. Comparing salt-sensitive and salt-tolerant wheat cultivars, it was hypothesized that Si could alleviate salt stress through two mechanisms: either by inhibition of $\mathrm{Na}^{+}$transport to leaves and/or by inhibition of specific accumulation of $\mathrm{Na}^{+}$in roots [89].

Silicon has been ascribed to increase tolerance of salt stressed cucumber and Sorghum [90] [91] through the accumulation of polyamines like putrescine, spermidine, and spermine. Such polyamine biosynthesis regulates $\mathrm{Na}^{+}$and $\mathrm{K}^{+}$ transport, enhances antioxidant ability and alters osmotic potential [92]. These polyamines prevent accumulation of $\mathrm{Na}^{+}$by blocking outward and inward $\mathrm{Na}^{+}$ and $\mathrm{K}^{+}$via non-selective channels [93].

Higher accumulation of soluble sugars under salinity has been reported in rice whereas silicon supplementation along with $\mathrm{NaCl}$ decreased soluble sugar contents [79] and consequently enhanced starch possibly through condensation of simple organic compounds, e.g., sugars, free amino acids, soluble phenols, into more complex ones, e.g., carbohydrates, protein, polyphenols.

Drought is one of the major environmental factors limiting productivity and growth. Silicon improves tolerance in several crops under deficit irrigation [94] [95] [96] by minimizing drought induced changes in transpiration rate, WUE, stomatal limitation value and net photosynthesis [97]. Silicon maintains higher relative water content, water potential and stomatal conductance in wheat subjected to drought when compared to control plants. The photosynthetic pigment contents, soluble proteins, total thiols as well as the activities of enzymes SOD, CAT and GR increased while $\mathrm{H}_{2} \mathrm{O}_{2}$ content, activity of acid phospholipase (AP) and level of oxidative stress proteins decreased in $\mathrm{Si}$ treated plants with respect to non-Si treated ones [94]. Silicon induced increase in photosynthesis under drought might be due to an increase in chlorophyll contents along with an enhancement in activities of photosynthetic enzymes ribulose-bisphosphate carboxylase and $\mathrm{NADP}^{+}$dependant glyceralde-3-phosphate dehydrogenase. Silicon reduces membrane peroxidation and regulates cellular osmolytes under drought.

Silicon fertilization improved development of secondary and tertiary cells of the endodermis allowing faster root growth and better resistance in dry soils [98] [99] and enhanced uptake of major elements in various grasses exposed to a wa- 
ter deficit [100]. Silicon addition improved wheat growth by stimulating antioxidant defenses and increased the plant biomass in wheat under short-term water stress conditions [96]. The net photosynthetic rate, chlorophyll content, activities of SOD, POD, CAT and APX were enhanced while increase of leaf plasma membrane permeability was restrained. Silicon primarily exerts its beneficial role in stressed plants, whereas in unstressed plants Si has little effects [101]. Application of Si caused minor changes in the transcriptome of unstressed rice and wheat [101] [102]. Contrastingly, long term studies on the effect of Si showed that $\mathrm{Si}$ increases crop yields in unstressed rice by lowering of transpiration by spikelets [103] [104]. Silicon alters source-sink relationship, increases photosynthesis, mesophyll conductance and helps in mobilization of photoassimilates, amino acids from vegetative tissues to grains in rice plants grown under normal condition [103] [104].

Seed priming with Si only for few hours fortifies plants against stressful events in the future. This "seed priming" is an aspect of Si research and is based mainly on biotic stress resistance [101] [105]. Limited research has been conducted on abiotic stress tolerance by $\mathrm{Si}$ seed priming. Silicon primed seeds showed increased germination rate, vegetative growth and yield under salt stress and osmotic stress over non-primed seeds [106] [107]. Though the exact mechanism is still unknown, seed priming could be a promising and cost-effective procedure to combat with major stresses including salinity.

\section{Physical Stresses}

Silicon prevents structural and functional deterioration of cell membranes induced by high temperature. Silicon also reduced the injury of thermal stress in Salvia by strengthening the cell wall [6]. Electrolyte leakage caused by high temperature in rice could be lowered by $\mathrm{Si}$ supplementation suggesting the involvement of Si in maintaining thermal stability of membrane lipids [108].

Chilling and low light conditions promote production of reactive oxygen species (ROS) which damages membrane lipids and cause cell death [109]. Silicon supplementation enhances resistance to freezing stress in winter wheat and protects chilling-stressed cucumber leaves from being damaged by ROS under low light [110] [111]. Exogenous Si reduced withering of cucumber leaves relative to the original chilling treatment, escalated the activities of antioxidant enzymes, viz.; SOD, glutathione peroxidase (GPx), APX, monodehydroascorbate reductase (MDHAR), GR, along with ascorbate (AsA), and GSH while reduced the levels of $\mathrm{H}_{2} \mathrm{O}_{2}, \mathrm{O}_{2}^{-}$, and MDA. In chilling-stressed cucumber leaves, exogenous $\mathrm{Si}$ supplementation enhanced the endogenous $\mathrm{Si}$ content that was associated with a decrease in lipid peroxidation.

Climatic stresses such as typhoons, low temperature and insufficient sunshine causes lodging and reduces yield in rice. Silicon fertilization improves such damages by enhancing rigidity and mechanical strength due to silicification of shoots and thereby prevents lodging [34]. Excess water loss from the spikelets 
due to strong winds results in sterility. Deposition of $\mathrm{Si}$ is effective in preventing the excess water loss. Additionally, Si improves rice yield under low temperature and insufficient sunshine [112]. Goto et al. [113] showed that Si supplemented rice plants absorbed less UV radiation $(280-320 \mathrm{~nm})$ than untreated ones due to protective effect of Si deposition on the leaf epidermis. Rice grew better after exposure to gamma rays if it had been previously fertilized with Si [1]. Shen et al. [95] showed that Si alleviated the adverse effects caused by ultraviolet-B (UV-B) radiation stress on soybean by increasing the stem length, net photosynthetic rate, leaf chlorophyll content and reduced the level of active oxygen species and electrolyte leakage. The rate of transpiration and stomatal conductance also decreased in soybean treated with Si under UV-B radiation which possibly improved water and nutrient storage within plant tissues reinforcing resistance against radiation effect. Similarly in wheat positive correlations were found with leaf silicon concentration and total biomass as well as chlorophyll content while malondialdehyde (MDA) content and production rate of superoxide radical were negatively correlated with leaf silicon concentration under UV-B stress. Silicon also enhanced the contents of soluble sugar and phenolic flavonoid compounds and alleviated the adverse effects of UV-B stress [113]. Accumulation of such flavonoids primarily in the epidermis limits the penetration of UV radiations and forms the first line of defense during UV stress [114].

\section{Conclusion}

Thus significant numbers of studies have reported a versatile potentiality of this metalloid to sustain plants during diverse stresses. Heightened anthropogenic activities, changing climatic conditions and the emerging pollution crisis have dismal effects on crop productivity and demands urgency in crop improvement practices. Imperative aspect for further studies on role of $\mathrm{Si}$ in plant biology would be employing $\mathrm{Si}$ in conferring tolerance to abiotic stresses consequently in environmental remediation. The favourable benefits of Si fertilization by natural silicates and low-cost industrial by-product sources have the potential to mitigate environmental stresses as well as soil nutrient depletion and can be an alternative to the extensive use of NPK fertilizers for restoring the soil integrity and maintaining sustainable productivity. Understanding these processes should form the basis of our future perspectives that would widen our knowledge of plant adaptation to undesirable environmental conditions and can be used to increase agricultural yields. Comprehensive analysis is therefore needed to appraise the role of Si in plant biology and acquire in-depth information to explore the mechanisms of Si mediated alleviation of several stresses. This may be conducive to develop cost effective and environmentally benign agriculture.

\section{Acknowledgements}

The authors thank and acknowledge all professional colleagues and scientists for their valuable contributions. Financial support by the University Grants Com- 
mission (UGC), New Delhi is also gratefully acknowledged.

\section{References}

[1] Ma, J.F. and Takahashi, E. (2002) Soil, Fertilizer, and Plant Silicon Research in Japan. Elsevier Science, Amsterdam, The Netherlands.

[2] Yamaji, N. and Ma, J.F. (2011) Further Characterization of a Rice Silicon Efflux Transporter, Lsi 2. Soil Science and Plant Nutrition, 57, 257-264. https://doi.org/10.1080/00380768.2011.565480

[3] Hodson, M.J., White, P.J., Mead, A. and Broadley, M.R. (2005) Phylogenetic Variation in the Silicon Composition of Plants. Annals of Botany, 96, 1027-1046. https://doi.org/10.1093/aob/mci255

[4] Ma, J.F., Tamai, K., Yamaji, N., Mitani, N., Konishi, S., Katsuhara, M., Ishiguro, M., Murata, Y. and Yano, M. (2006) A Silicon Transporter in Rice. Nature, 440, 688-691. https://doi.org/10.1038/nature04590

[5] Deshmukh, R.K., Vivancos, J., Ramakrishnan, G., Guérin, V., Carpentier, G., Sonah, H., et al. (2015) A Precise Spacing between the NPA Domains of Aquaporins Is Essential for Silicon Permeability in Plants. The Plant Journal, 83, 489-500. https://doi.org/10.1111/tpj.12904

[6] Soundararajan, P., Sivanesan, I., Jana, S. and Jeong, B.R. (2014) Influence of Silicon Supplementation on the Growth and Tolerance to High Temperature in Salvia splendens. Horticulture, Environment and Biotechnology, 55, 271-279. https://doi.org/10.1007/s13580-014-0023-8

[7] Zhang, Q., Liu, J., Lu, H., Zhao, S., Wang, W., Du, J., et al. (2015) Effects of Silicon on Growth, Root Anatomy, Radial Oxygen Loss (ROL) and Fe/Mn Plaque of Aegiceras corniculatum (L.) Blanco Seedlings Exposed to Cadmium. Environmental Nanotechnology, Monitoring and Management, 4, 6-11. https://doi.org/10.1016/j.enmm.2015.04.001

[8] Ma, J.F. (2004) Role of Silicon in Enhancing the Resistance of Plants to Biotic and Abiotic Stresses. Soil Science and Plant Nutrition, 50, 11-18. https://doi.org/10.1080/00380768.2004.10408447

[9] Liang, Y., Sun, W., Zhu, Y.G. and Christie, P. (2007) Mechanisms of Silicon Mediated Alleviation of Abiotic Stresses in Higher Plants: A Review. Environmental Pollution, 147, 422-428. https://doi.org/10.1016/j.envpol.2006.06.008

[10] Cookson, L.J., Scown, D.K., McCarthy, K.J. and Chew, N. (2007) The Effectiveness of Silica Treatments against Wood-Boring Invertebrates. Holzforschung, 61, 326-332. https://doi.org/10.1515/HF.2007.045

[11] Mitani, N., Ma, J.F. and Iwashita, T. (2005) Identification of the Silicon from in Xylem Sap of Rice (Oryza sativa L.). Plant and Cell Physiology, 46, 279-283. https://doi.org/10.1093/pcp/pci018

[12] Jones, L.H.P. and Handreck, K.A. (1967) Silica in Soils, Plants, and Animals. Advances in Agronomy, 19, 107-149. https://doi.org/10.1016/S0065-2113(08)60734-8

[13] Ma, J.F. (2010) Silicon Transporters in Higher Plants. In: Thomas, P.J. and Gerd, P.B., Eds., MIPs and Their Role in the Exchange of Metalloids, Springer, Austin, 99-109. https://doi.org/10.1007/978-1-4419-6315-4_8

[14] Yamaji, N., Mitani, N. and Ma, J.F. (2008) A Transporter Regulating Silicon Distribution in Rice Shoots. The Plant Cell, 20, 1381-1389.

https://doi.org/10.1105/tpc.108.059311

[15] Mitani, N., Chiba, Y. and Yamaji, N. (2009) Identification and Characterization of 
Maize and Barley Lsi2-Like Silicon Efflux Transporters Reveals a Distinct Silicon Uptake System from that in Rice. The Plant Cell, 21, 2133-2142. https://doi.org/10.1105/tpc.109.067884

[16] Pontigo, S., Ribera, A., Gianfreda, L. and Mora, M.D.L.L. (2015) Silicon in Vascular Plants: Uptake, Transport and Its Influence on Mineral Stress under Acidic Conditions. Planta, 242, 23-37. https://doi.org/10.1007/s00425-015-2333-1

[17] Mitani, N., Yamaji, N. and Ma, J.F. (2009) Identification of Maize Silicon Influx Transporters. Plant and Cell Physiology, 50, 5-12.

[18] Ashraf, M.A., Morshed, M.M., Saleh Ahammad, A.J. and Morshed, M.N. (2013) Computational Study of Silicon Transporter Protein in Rice and Wheat. International Journal of Computational Bioinformatics and In Silico Modeling, 2, 199-205.

[19] Richmond, K.E. and Sussman, M. (2003) Got Silicon? The Non-Essential Beneficial Plant Nutrient. Current Opinion in Plant Biology, 6, 268-272. https://doi.org/10.1016/S1369-5266(03)00041-4

[20] Ma, J.F. and Yamaji, N. (2006) Silicon Uptake and Accumulation in Higher Plants. Trends in Plant Science, 11, 392-397. https://doi.org/10.1016/j.tplants.2006.06.007

[21] Lee, S., Sohn, E. and Hamayun, M. (2010) Effect of Silicon on Growth and Salinity Stress of Soybean Plant Grown under Hydroponic System. Agroforestry Systems, 80, 333-340. https://doi.org/10.1007/s10457-010-9299-6

[22] Rafi, M.M., Epstein, E. and Falk, R.H. (1997) Silicon Deprivation Causes Physical Abnormalities in Wheat (Triticum aestivum L.). Journal of Plant Physiology, 151, 497-501. https://doi.org/10.1016/S0176-1617(97)80017-X

[23] Adaita, M.H. and Besford, R.T. (1986) The Effects of Silicon on Cucumber Plants Grown in Recirculating Nutrient Solution. Annals of Botany, 58, 343-351. https://doi.org/10.1093/oxfordjournals.aob.a087212

[24] Fawe, A., Menzies, J.G., Chérif, M. and Bélanger R.R. (2001) Silicon and Disease Resistance in Dicotyledons. In: Datnoff, L.E., Snyder, G.H. and Korndöfer, G.H., Eds., Silicon in Agriculture, Elsevier, Amsterdam, 159-170.

[25] Ghanmi, D., McNally, D.J., Benhamou, N., Menzies, J.G. and Bélanger, R.R. (2004) Powdery Mildew of Arabidopsis thaliana: A Pathosystem for Exploring the Role of Silicon in Plant-Microbe Interactions. Physiological and Molecular Plant Pathology, 64, 189-199. https://doi.org/10.1016/j.pmpp.2004.07.005

[26] Rémus-Borel, W., Menzies, J.G. and Bélanger, R.R. (2005) Silicon Induces Antifungal Compounds in Powdery Mildew-Infected Wheat. Physiological and Molecular Plant Pathology, 66, 108-115. https://doi.org/10.1016/j.pmpp.2005.05.006

[27] Rémus-Borel, W., Menzies, J.G. and Bélanger, R.R. (2009) Aconitate and Methyl Aconitate Are Modulated by Silicon in Powdery Mildew-Infected Wheat Plants. Journal of Plant Physiology, 166, 1413-1422. https://doi.org/10.1016/j.jplph.2009.02.011

[28] Rodgers-Gray, B.S. and Shaw, M.W. (2004) Effects of Straw and Silicon Soil Amendments on Some Foliar and Stem-Base Diseases in Pot-Grown Winter Wheat. Plant Pathology, 53, 733-740. https://doi.org/10.1111/j.1365-3059.2004.01102.x

[29] Savant, N.K., Snyder, G.H. and Datnoff, L.E. (1996) Silicon Management and Sustainable Rice Production. Advances in Agronomy, 58, 151-199. https://doi.org/10.1016/S0065-2113(08)60255-2

[30] Fauteux, F., Remus-Borel, W., Menzies, J.G. and Belanger, R.R. (2005) Silicon and Plant Disease Resistance against Pathogenic Fungi. FEMS Microbiology Letters, 249, 1-6. https://doi.org/10.1016/j.femsle.2005.06.034 
[31] Guevel, M.H., Menzies, J.G. and Bélanger, R.R. (2007) Effect of Root and Foliar Applications of Soluble Silicon on Powdery Mildew Control and Growth of Wheat Plants. European Journal of Plant Pathology, 119, 429-436. https://doi.org/10.1007/s10658-007-9181-1

[32] Cotterill, J.V., Watkins, R.W., Brennon, C.B. and Cowan, D.P. (2007) Boosting Silica Levels in Wheat Leaves Reduces Grazing by Rabbits. Pest Management Science, 63, 247-253. https://doi.org/10.1002/ps.1302

[33] Hunt, J.W., Dean, A.P., Webster, R.E., Johnson, G.N. and Ennos, A.R. (2008) A Novel Mechanism by which Silica Defends Grasses against Herbivory. Annals of Botany, 102, 653-656. https://doi.org/10.1093/aob/mcn130

[34] Han, Y., Li, P., Gong, S., Yang, L., Wen, L. and Hou, M. (2016) Defense Responses in Rice Induced by Silicon Amendment against Infestation by the Leaf Folder Cnaphalocrocis medinalis. PLOS ONE, 11, e0153918. https://doi.org/10.1371/journal.pone.0153918

[35] Lux, A., Luxov'a, M., Abe, J., Tanimoto, E., Hattori, T. and Inanaga, S. (2003) The Dynamics of Silicon Deposition in the Sorghum Root Endodermis. New Phytologist, 158, 437-441. https://doi.org/10.1046/j.1469-8137.2003.00764.x

[36] Ma, J.F. and Takahashi, E. (1990) The Effect of Silicic Acid on Rice in a P-Deficient Soil. Plant and Soil, 126, 121-125. https://doi.org/10.1007/BF00041377

[37] Miyake, Y. and Takahashi, E. (1983) Effect of Silicon on the Growth of Solution-Cultured Cucumber Plant. Soil Science and Plant Nutrition, 29, 71-83. https://doi.org/10.1080/00380768.1983.10432407

[38] Miyake, Y. and Takahashi, E. (1985) Effect of Silicon on the Growth of Soybean Plants in a Solution Culture. Soil Science and Plant Nutrition, 31, 625-636. https://doi.org/10.1080/00380768.1985.10557470

[39] Miyake, Y. and Takahashi, E. (1986) Effect of Silicon on the Growth and Fruit Production of Strawberry Plants in a Solution Culture. Soil Science and Plant Nutrition, 32, 321-326. https://doi.org/10.1080/00380768.1986.10557510

[40] Ma, J.F. and Takahashi, E. (1990) Effect of Silicon on the Growth and Phosphorus Uptake of Rice. Plant and Soil, 126, 115-119. https://doi.org/10.1007/BF00041376

[41] Ohyama, N. (1985) Amelioration of Cold Weather Damage of Rice by Silicate Fertilizer Application. Agriculture and Horticulture, 60, 1385-1389.

[42] Gunes, A., Inal, A., Bagci, E.G., Coban, S. and Sahin, O. (2007) Silicon Increases Boron Tolerance and Reduces Oxidative Damage of Wheat Grown in Soil with Excess Boron. Biologia Plantarum, 51, 571-574. https://doi.org/10.1007/s10535-007-0125-6

[43] Inal, A., Pilbeam, D.J. and Gunes, A. (2009) Silicon Increases Tolerance to Boron toxicity and Reduces Oxidative Damage in Barley. Journal of Plant Nutrition, 32, 112-128. https://doi.org/10.1080/01904160802533767

[44] Gunes, A., Inal, A., Bagci, E.G., Coban, S. and Pilbeam, D.J. (2007) Silicon Mediates Changes to Some Physiological and Enzymatic Parameters Symptomatic for Oxidative Stress in Spinach (Spinacia oleracea L.) Grown under B Toxicity. Scientia Horticulturae, 113, 113-119. https://doi.org/10.1016/j.scienta.2007.03.009

[45] Tripathi, P., Tripathi, R.D., Singh, R.P., Dwivedi, S., Goutam, D., Shri, M., Trivedi, P.K. and Chakrabarty, D. (2013) Silicon Mediates Arsenic Tolerance in Rice (Oryza sativa L.) Through Lowering of Arsenic Uptake and Improved Antioxidant Defense System. Ecological Engineering, 52, 96-103. https://doi.org/10.1016/j.ecoleng.2012.12.057 
[46] Da Silva, A.J., Williams, N.C., Da Silva, G.N.A. and Silva E.A. (2015) Effects of Silicon on Alleviating Arsenic Toxicity in Maize Plants. Brazilian Journal of Soil Science, 39,289-296. https://doi.org/10.1590/01000683rbcs20150176

[47] Fleck, A.T, Mattusch, J. and Schenk, M.K. (2013) Silicon Decreases the Arsenic Level in Rice Grain by Limiting Arsenite Transport. Journal of Plant Nutrition and Soil Science, 176, 785-794. https://doi.org/10.1002/jpln.201200440

[48] Williams, D.E. and Vlamis, J. (1957) The Effect of Silicon on Yield and Manganese-54 Uptake and Distribution in the Leaves of Barley Plants Grown in Culture Solutions. Plant Physiology, 32, 404-409. https://doi.org/10.1104/pp.32.5.404

[49] Horst, W.J., Fecht, M., Naumann, A., Wissemeier, A.H. and Maier, P. (1999) Physiology of Manganese Toxicity and Tolerance in Vigna unguiculata(L.) Walp. Journal of Plant Nutrition and Soil Science, 162, 263-274. https://doi.org/10.1002/(SICI)1522-2624(199906)162:3<263::AID-JPLN263>3.0.CO; 2-A

[50] Iwasaki, K., Maier, P., Fecht, M. and Horst, W.J. (2002) Effects of Silicon Supply on Apoplastic Manganese Concentrations in Leaves and their Relation to Manganese Tolerance in Cowpea (Vigna unguiculate (L.)Walp.). Plant and Soil, 238, 281-288. https://doi.org/10.1023/A:1014482911196

[51] Iwasaki, K., Maier, P., Fecht, M. and Horst, W.J. (2002) Leaf Apoplastic Silicon Enhances Manganese Tolerance of Cowpea (Vigna unguiculata). Journal of Plant Physiology, 159, 167-173. https://doi.org/10.1078/0176-1617-00691

[52] Rogalla, H. and Romheld, V. (2002) Role of Leaf Apoplast in Silicon-Mediated Manganese Tolerance of Cucumis sativus L. Plant Cell and Environment, 25, 549-555. https://doi.org/10.1046/j.1365-3040.2002.00835.x

[53] Shi, Q.H., Bao, Z.Y., Zhu, Z.J., He, Y., Qian, Q.Q. and Yu, J.Q. (2005) Silicon-Mediated Alleviation of Mn Toxicity in Cucumis sativus in Relation to Activities of Superoxide Dismutase and Ascorbate Peroxidase. Phytochemistry, 66, 1551-1559. https://doi.org/10.1016/j.phytochem.2005.05.006

[54] Farooq, M.A., Ali, S., Hameed, A., Ishaque, W., Mahmood, K. and Iqbal, Z. (2013) Alleviation of Cadmium Toxicity by Silicon Is Related to Elevated Photosynthesis, Antioxidant Enzymes; Suppressed Cadmium Uptake and Oxidative Stress in Cotton. Ecotoxicology and Environmental Safety, 96, 242-249. https://doi.org/10.1016/j.ecoenv.2013.07.006

[55] Song, A.L., Li, Z.J., Zhang, J., Xue, G.F., Fan, F.L. and Liang, Y.C. (2009) Silicon-Enhanced Resistance to Cadmium Toxicity in Brassica chinensis L. Is Attributed to Si-Suppressed Cadmium Uptake and Transport and Si-Enhanced Antioxidant Defence Capacity. Journal of Hazardous Materials, 172, 74-83. https://doi.org/10.1016/j.jhazmat.2009.06.143

[56] Shi, X., Zhang, C., Wang, H. and Zhang, F. (2005) Effect of Si on the Distribution of Cd in Rice Seedlings. Plant and Soil, 272, 53-60. https://doi.org/10.1007/s11104-004-3920-2

[57] Vaculík, M., Landberg, T., Greger, M., Luxova, M., Stoláriková, M. and Lux, A. (2012) Silicon Modifies Root Anatomy, and Uptake and Subcellular Distribution Cadmium in Young Maize Plants. Annals of Botany, 110, 433-443. https://doi.org/10.1093/aob/mcs039

[58] Bharwana, S.A., Ali, S., Farooq, M.A., Iqbal, N., Abbas, F. and Ahmad, M.S.A. (2013) Alleviation of Lead Toxicity by Silicon Is Related to Elevated Photosynthesis, Antioxidant Enzymes Suppressed Lead Uptake and Oxidative Stress in Cotton. Bioremediation and Biodegradation, 4, 446-455. 
[59] Liu, J., Cai, H., Mei, C. and Wang, M. (2015) Effects of Nano-Silicon and Common Silicon on Lead Uptake and Translocation in Two Rice Cultivars. Frontiers of Environmental Science and Engineering, 9, 905-911. https://doi.org/10.1007/s11783-015-0786-x

[60] Hammond, K.E., Evans, D.E. and Hodson, M.J. (1995) Aluminium/Silicon Interactions in Barley (Hordeum vulgare L.) Seedlings. Plant and Soil, 173, 89-95. https://doi.org/10.1007/BF00155521

[61] Wang, Y., Stass, A. and Horst, W.J. (2004) Apoplastic Binding of Aluminum Is Involved in Silicon-Induced Amelioration of Aluminium Toxicity in Maize. Plant Physiology, 136, 3762-3770.

[62] Kidd, P.S., Llugany, M., Poschenrieder, C., Gunse, B. and Barcelo, J. (2001) The Role of Root Exudates in Aluminium Resistance and Silicon-Induced Amelioration of Aluminium Toxicity in Three Varieties of Maize (Zea mays L.). Journal of Experimental Botany, 52, 1339-1352.

[63] Cocker, K.M., Evans, D.E. and Hodson, M.J. (1998) The Amelioration of Aluminium Toxicity by Silicon in Wheat (Triticum aestivum L.): Malate Exudation as Evidence for an In-Planta Mechanism? Planta, 204, 318-323. https://doi.org/10.1007/s004250050262

[64] Shen, X., Xiao, X., Dong, Z. and Chen, Y. (2014) Silicon Effects on Antioxidative Enzymes and Lipid Peroxidation in Leaves and Roots of Peanut under Aluminum Stress. Acta Physiologiae Plantarum, 36, 3063-3069. https://doi.org/10.1007/s11738-014-1676-8

[65] De Jesus, L.R., Batista B.L. and Da Silva, L.A.K. (2017) Silicon Reduces Aluminium Accumulation and Mitigates Toxic Effects in Cowpea Plants. Acta Physiologiae Plantarum, 39, 138. https://doi.org/10.1007/s11738-017-2435-4

[66] Song, A., Li, P., Fan, F., Li, Z. and Liang, Y. (2014) The Effect of Silicon on Photosynthesis and Expression of Its Relevant Genes in Rice (Oryza sativa L.) under High Zinc Stress. PLoS ONE, 9, 11. https://doi.org/10.1371/journal.pone.0113782

[67] Neumann, D. and Zurnieden, U. (2001) Silicon and Heavy Metal Tolerance of Higher Plants. Phytochemistry, 56, 685-692.

https://doi.org/10.1016/S0031-9422(00)00472-6

[68] Gu, H.H., Zhan, S.S., Wang, S.Z., Tang, Y.T., Chaney, R.L., Fang, H.X., Cai, X.D. and Qiu, R.L. (2012) Silicon Mediated Amelioration of Zinc Toxicity in Rice (Oryza sativa L.) Seedlings. Plant and Soil, 350, 193-204.

https://doi.org/10.1007/s11104-011-0894-8

[69] Ali, S., Farooq, M.A., Yasmeen, T., Hussain, S., Arif, M.S., Abbas, F., Bharwana, S.A. and Zhang, G.P. (2013) The Influence of Silicon on Barley Growth, Photosynthesis and Ultra-Structure under Chromium Stress. Ecotoxicology and Environmental Safety, 89, 66-72. https://doi.org/10.1016/j.ecoenv.2012.11.015

[70] Tripathi, D.K., Singh, V.P., Prasad, S.M., Chauhan, D.K., Dubey, N.K. and Rai, A.K. (2015) Silicon-Mediated Alleviation of Cr(VI) Toxicity in Wheat Seedlings as Evidenced by Chlorophyll Florescence, Laser Induced Breakdown Spectroscopy and Anatomical Changes. Ecotoxicology and Environmental Safety, 113, 133-144. https://doi.org/10.1016/j.ecoenv.2014.09.029

[71] Tripathi, D.K., Singh, V.P., Kumar, D. and Chauhan, D.K. (2012) Impact of Exogenous Silicon Addition on Chromium Uptake, Growth, Mineral Elements, Oxidative Stress, Antioxidant Capacity, and Leaf and Root Structures in Rice Seedlings Exposed to Hexavalent Chromium. Acta Physiologiae Plantarum, 34, 279-289. https://doi.org/10.1007/s11738-011-0826-5 
[72] Khaliq, A., Ali, S., Hameed, A., Farooq, M.A., Farid, M., Shakoor, M.B., Mahmood, K., Ishaque, W. and Rizwan, M. (2016) Silicon Alleviated Nickel Toxicity in Cotton Seedlings through Enhancing Growth, Photosynthesis and Suppressing Ni Uptake and Oxidative Stress. Archives of Agronomy and Soil Science, 62, 633-647.

[73] Frantz, J.M. (2011) Silicon Differentially Influences Copper Toxicity Response in Silicon-Accumulator and Non-Accumulator Species. Journal of the American Society for Horticultural Science, 136, 329-338.

[74] Li, J., Leisner, S.M. and Frantz, J. (2008) Alleviation of Copper Toxicity in Arabidopsis thaliana by Silicon Addition to Hydroponic Solutions. Journal of the American Society for Horticultural Science, 133, 670-677.

[75] Matoh, T., Kairusmee, P. and Takahashi, E. (1986) Salt-Induced Damage to Rice Plants and Alleviation Effect of Silicate. Journal of Soil Science and Plant Nutrition, 32,295-304. https://doi.org/10.1080/00380768.1986.10557506

[76] Yeo, A.R., Flowers, S.A., Rao, G., Welfare, K., Senanayake, N. and Flowers, T.J. (1999) Silicon Reduces Sodium Uptake in Rice (Oryza sativa L.) in Saline Conditions and This Is Accounted for by a Reduction in the Transpirational Bypass Flow. Plant Cell Environment, 22, 559-565. https://doi.org/10.1046/j.1365-3040.1999.00418.x

[77] Al-Aghabary, K., Zhu, Z. and Shi, Q.H. (2004) Influence of Silicon Supply on Chlorophyll Content, Chlorophyll Fluorescence, and Antioxidative Enzyme Activities in Tomato Plants under Salt Stress. Journal of Plant Nutrition, 27, 2101-2115. https://doi.org/10.1081/PLN-200034641

[78] Zhu, Z.J., Wei, G.Q., Li, J., Qian, Q.Q. and Yu, J.Q. (2004) Silicon Alleviates Salt Stress and Increases Antioxidant Enzymes Activity in Leaves of Salt-Stressed Cucumber (Cucumis sativus L.). Plant Science, 167, 527-533. https://doi.org/10.1016/j.plantsci.2004.04.020

[79] Das, P., Seal, P. and Biswas, A.K. (2016) Regulation of Growth, Antioxidants and Sugar Metabolism in Rice (Oryza sativa L.) Seedlings by $\mathrm{NaCl}$ and Its Reversal by Silicon. American Journal of Plant Sciences, 7, 623-638. https://doi.org/10.4236/ajps.2016.73055

[80] Liang, Y., Chen, Q., Liu, Q., Zhang, W. and Ding, R. (2003) Exogenous Silicon Increases Antioxidant Enzyme Activity and Reduces Lipid Peroxidation in Roots of Salt-Stressed Barley (Hordeum vulgare L.). Journal of Plant Physiology, 160, 1157-1164. https://doi.org/10.1078/0176-1617-01065

[81] Shi, Y., Zhang, Y., Han, W., Feng, R., Hu, Y. and Guo, J. (2016) Silicon Enhances Water Stress Tolerance by Improving Root Hydraulic Conductance in Solanum lycopersicum L. Frontiers in Plant Science, 7, 196. https://doi.org/10.3389/fpls.2016.00196

[82] Liang, Y., Nikolic, M., Bélanger, R., Gong, H. and Song, A. (2015) Silicon in Agriculture. Springer, Dordrecht. https://doi.org/10.1007/978-94-017-9978-2

[83] Nwugo, C.C. and Huerta, A.J. (2011) The Effect of Silicon on the Leaf Proteome of Rice (Oryza sativa L.) Plants under Cadmium-Stress. Journal of Proteome Research, 10, 518-528. https://doi.org/10.1021/pr100716h

[84] Gong, H.J., Randall, D.P. and Flowers, T.J. (2006) Silicon Deposition in the Root Reduces Sodium Uptake in Rice (Oryza sativa L.) Seedlings by Reducing Bypass Flow. Plant, Cell and Environment, 29, 1970-1979. https://doi.org/10.1111/j.1365-3040.2006.01572.x

[85] Ashraf, M., Rahmatullah, A.M., Ahmed, R., Mujeeb, F., Sarwar, A. and Ali, L. (2010) Alleviation of Detrimental Effects of $\mathrm{NaCl}$ by Silicon Nutrition in 
Salt-Sensitive and Salt-Tolerant Genotypes of Sugarcane (Saccharum officinarum L.). Plant and Soil, 326, 381-391. https://doi.org/10.1007/s11104-009-0019-9

[86] Kafi, M. and Rahimi, Z. (2010) Salinity Effects on Germination Properties of Purslane (Portulaca oleracea L.). Iranian Journal of Field Crops Research, 8, 615-621.

[87] Liang, Y.C., Zhang, W.H., Chen, Q., Liu, Y.L. and Ding, R.X. (2006) Effect of Exogenous Silicon $(\mathrm{Si})$ on $\mathrm{H}^{+}$-ATPase Activity, Phospholipids and Fluidity of Plasma Membrane in Leaves of Salt-Stressed Barley (Hordeum vulgare L.). Environmental and Experimental Botany, 57, 212-219.

https://doi.org/10.1016/j.envexpbot.2005.05.012

[88] Liang, Y.C. (1999) Effects of Silicon on Enzyme Activity, and Sodium, Potassium and Calcium Concentration in Barley under Salt Stress. Plant and Soil, 209, 217-224. https://doi.org/10.1023/A:1004526604913

[89] Tuna, A.L., Kaya, C., Higgs, D., Murillo-Amador, B., Aydemir, S. and Girgin, A.R. (2008) Silicon Improves Salinity Tolerance in Wheat Plants. Environmental and Experimental Botany, 62, 10-16. https://doi.org/10.1016/j.envexpbot.2007.06.006

[90] Wang, S., Liu, P., Chen, D., Yin, L., Li, H. and Deng, X. (2015) Silicon Enhanced Salt Tolerance by Improving the Root Water Uptake and Decreasing the Ion Toxicity in Cucumber. Frontiers in Plant Science, 6, 759. https://doi.org/10.3389/fpls.2015.00759

[91] Yin, L., Wang, S., Tanaka, K., Fujihara, S., Itai, A. and Den, X. (2016) Silicon Mediated Changes in Polyamines Participate in Silicon-Induced Salt Tolerance in Sorghum bicolor L. Plant Cell Environment, 39, 245-258. https://doi.org/10.1111/pce.12521

[92] Alcazar, R., Altabella, T., Marco, F., Bortolotti, C., Reymond, M. and Koncz, C. (2010) Polyamines: Molecules with Regulatory Functions in Plant Abiotic Stress Tolerance. Planta, 231, 1237-1249. https://doi.org/10.1007/s00425-010-1130-0

[93] Zhao, F., Song, C.P., He, J. and Zhu, H. (2007) Polyamines Improve $\mathrm{K}^{+} / \mathrm{Na}^{+} \mathrm{Ho}-$ meostasis in Barley Seedlings by Regulating Root Ion Channel Activities. Plant Physiology, 145, 1061-1072. https://doi.org/10.1104/pp.107.105882

[94] Gong, H.Z., Chen, K., Wang, S. and Zhang, C. (2005) Silicon Alleviates Oxidative Damage of Wheat Plants in Pots under Drought. Plant Science, 169, 313-321. https://doi.org/10.1016/j.plantsci.2005.02.023

[95] Shen, X., Zhou, Y., Duan, L., Eneji, A.E. and Li, J. (2010) Silicon Effects on Photosynthesis and Antioxidant Parameters of Soybean Seedlings under Drought and Ultraviolet-B Radiation. Journal of Plant Physiology, 167, 1248-1252. https://doi.org/10.1016/j.jplph.2010.04.011

[96] Pei, Z.F., Ming, D.F., Liu, D., Wan, G.L., Geng, X.X., Gong, H.J. and Zhou, W.J. (2010) Silicon Improves the Tolerance of Water-Deficit Stress Induced by Polyethylene Glycol in Wheat (Triticum aestivum L.) Seedlings. Journal of Plant Growth Regulation, 29, 106-115. https://doi.org/10.1007/s00344-009-9120-9

[97] Ahmed, M., Hassen, F.U., Qadeer, U. and Aslam, M.A. (2011) Silicon Application and Drought Tolerance Mechanism of Sorghum. African Journal of Agricultural Research, 6, 594-607.

[98] Hattori, T., Inanaga, S., Tanimoto, E., Lux, A., Luxova, M. and Sugimoto, Y. (2003) Silicon-Induced Changes in Visco Elastic Properties of Sorghum Root Cell Walls. Plant and Cell Physiology, 44, 743-749. https://doi.org/10.1093/pcp/pcg090

[99] Hattori, T., Inanaga, H., Araki, H., An, P., Morita, S., Luxova, M. and Lux, A. (2005) Application of Silicon Enhanced Drought Tolerance in Sorghum bicolor. Physiologia Plantarum, 123, 459-466. https://doi.org/10.1111/j.1399-3054.2005.00481.x 
[100] Eneji, A.E., Inanaga, S., Muranaka, S., Li, J., Hattori, T., An, P. and Tsuji, W. (2008) Growth and Nutrient Use in Four Grasses under Drought Stress as Mediated by Silicon Fertilizers. Journal of Plant Nutrition, 31, 355-365.

https://doi.org/10.1080/01904160801894913

[101] Van Bockhaven, J., De Vleesschauwer, D. and Hofte, M. (2013) Towards Establishing Broad-spectrum Disease Resistance in Plants: Silicon Leads the Way. Journal of Experimental Botany, 64, 1281-1293. https://doi.org/10.1093/jxb/ers329

[102] Chain, F., Côté-Beaulieu, C., Belzile, F., Menzies, J.G. and Bélanger, R.R. (2009) A Comprehensive Transcriptomic Analysis of the Effect of Silicon on Wheat Plants under Control and Pathogen Stress Conditions. Molecular Plant Microbe Interactions, 22, 1323-1330. https://doi.org/10.1094/MPMI-22-11-1323

[103] Detmann, K.C., Araújo, W.L., Martins, S.C., Sanglard, L.M., Reis, J.V. and Detmann, E. (2012) Silicon Nutrition Increases Grain Yield, which, in Turn, Exerts a Feed-Forward Stimulation of Photosynthetic Rates via Enhanced Mesophyll Conductance and Alters Primary Metabolism in Rice. New Phytologist, 196, 752-762. https://doi.org/10.1111/j.1469-8137.2012.04299.x

[104] Detmann, K., Araújo, W., Martins, S., Fernie, A.R. and DaMatta, F. (2013) Metabolic Alterations Triggered by Silicon Nutrition: Is There a Signalling Role for Silicon? Plant Signalling and Behaviour, 8, e22523. https://doi.org/10.4161/psb.22523

[105] Conrath, U. (2011) Molecular Aspects of Defence Priming. Trends in Plant Science, 16, 524-531. https://doi.org/10.1016/j.tplants.2011.06.004

[106] Azeem, M., Iqbal, N., Kausar, S., Javed, M.T., Akram, M.S. and Sajid, M.A. (2015) Efficacy of Silicon Priming and Fertigation to Modulate Seedling's Vigor and Ion Homeostasis in Wheat (Triticum aestivum L.) under Saline Environment. Environmental Science and Pollution Research International, 22, 14367-14371. https://doi.org/10.1007/s11356-015-4983-8

[107] Ahmed, M., Qadeer, U., Ahmed, Z.I. and Fayyaz-Ul, H. (2016) Improvement of Wheat (Triticum aestivum) Drought Tolerance by Seed Priming with Silicon. Archives of Agronomy and Soil Science, 62, 299-315. https://doi.org/10.1080/03650340.2015.1048235

[108] Agarie, S., Hanaoka, N., Ueno, O., Miyazaki, A., Kubota, F., Agata, W. and Kaufman, P.B. (1998) Effect of Silicon on Tolerance to Water Deficit and Heat Stress in Rice Plants (Oryza sativa L.), Monitored by Electrolyte Leakage. Plant Production Science, 1, 96-103. https://doi.org/10.1626/pps.1.96

[109] Xu, P.L., Guo, Y.K., Bai, J.G., Shang, L. and Wang, X.J. (2008) Effects of Long-Term Chilling on Ultra Structure and Antioxidant Activity in Leaves of Two Cucumber Cultivars under Low Light. Physiologia Plantarum, 132, 467-478. https://doi.org/10.1111/j.1399-3054.2007.01036.x

[110] Liang, Y., Zhu, J., Li, Z., Chu, G., Ding, Y., Zhang, J. and Sun, W. (2008) Role of Silicon in Enhancing Resistance to Freezing Stress in Two Contrasting Winter Wheat Cultivars. Environmental and Experimental Botany, 64, 286-294.

https://doi.org/10.1016/j.envexpbot.2008.06.005

[111] Liu, J., Lin, S., Xu, P. and Wang, X.J. (2009) Effects of Exogenous Silicon on the Activities of Antioxidant Enzymes and Lipid Peroxidation in Chilling-Stressed $\mathrm{Cu}$ cumber Leaves. Agricultural Science in China, 8, 1075-1086. https://doi.org/10.1016/S1671-2927(08)60315-6

[112] Ma, J., Miyake, Y., Takahashi, E. (2001) Silicon as a Beneficial Element for Crop Plants. In: Datnoff, L.E., Snyder, G.H. and Korndorfer, G.H., Eds., Silicon in Agriculture, Elsevier Science, Amsterdam, 17-39. https://doi.org/10.1016/S0928-3420(01)80006-9 
[113] Goto, M., Ehara, H., Karita, S., Takabe, K., Ogawa, N., Yamada, Y., Ogawa, S., Yahaya, M.S. and Morita, O. (2003) Protective Effect of Silicon on Phenolic Biosynthesis and Ultraviolet Spectral Stress in Rice Crop. Plant Science, 164, 349-356. https://doi.org/10.1016/S0168-9452(02)00419-3

[114] Yao, X., Chu, J., Cai, K., Liu, L., Shi, J. and Geng, W. (2011) Silicon Improves the Tolerance of Wheat Seedlings to Ultraviolet-B Stress. Biological Trace Element Research, 143, 507-517. https://doi.org/10.1007/s12011-010-8859-y 